\title{
Test of FCFE Model and Dividend Discount Model in Book 4 Banking Companies Listed in Indonesia Stock Exchange
}

\author{
R. Hendrawan *, T.Z. Rahayu \\ Telkom University \\ Bandung, Indonesia \\ * riko_hendrawan@yahoo.com
}

\begin{abstract}
The banking industry is one of the industries that shares in great demand by the people who will invest in the capital market. Not only interested by local investors but also even banking industry stocks are in great demand from foreign investors. The purpose of this research is to know the fair price of shares in banking companies in 2017 by using the method of Free Cash Flow to Equity on the growth scenario in pessimistic, moderate and optimistic conditions and to know the fair price of shares in banking companies, in 2017 by using Dividend Discount Model Method. The sampling technique used purposive sampling and chose 4 Banking Com panies which entered into book 4 category as research sample. Finding from this research shows that, using FCFE Model BBNI, BMRI and BBCA are undervalued, that stock market price is lower than fair value of company stock, while BBRI show overvalued and by using DDM calculation method all stock show undervalued. If it is known whether the stock is undervalued, fair valued, or overvalued, then the investor can be more confident to determine his investment decision. Whether the stock wants to be bought, retained or sold.
\end{abstract}

\section{Keywords—FCFE Model; Dividend Discount; Stock}

\section{INTRODUCTION}

State-Owned Enterprise Capital Market becomes an alternative for investors besides investment alternatives such as buying gold, saving in bank, land, insurance, building and others. The capital market is the whole organized financial system including commercial banks and all financial intermediaries and long-term and short-term securities [1]. In 2014-2016 the resilience of the banking system remains stable amid the economic slow down that exists in Indonesia, and the performance of the domestic financial market in general is also still quite good. The level of health of financial services institutions is also still maintained with the support of high capital and adequate liquidity.

Based on the list of 45 shares included in the calculation of LQ45 index for the period of August 2016 January 2017 at Indonesia Stock Exchange (IDX) in accordance with the announcement of Indonesia Stock Exchange No: Peng-00671 / BEI.OPP / 07-2016 dated July 26, 2017 and from 45 existing shares, there are 6 banking companies listed on the LQ45 Index from August 2016 to January 2017, namely Bank Mandiri, Bank Central Asia (BCA), Bank Rakyat Indonesia (BRI), Bank Negara Indonesia (BNI), Bank Tabungan Negara (BTN) and BPD West Java and Banten (BJB). Apart from the Banking sectors contained in the Bank LQ45 Index are grouped into 4 Books measured by the core capital held by Book 1 with a core capital of less than 1 trillion rupiah, book 2 with Core Capital of between one trillion and five trillion, Book 3 core capital of at least five trillion and Book 4 with Core Capital of at least thirty trillion (Rule of Financial Services Authority No.6 / POJK.03 / 2016).

With the grouping of banks into book 4 which is based on the amount of core capital, there are 4 banks from 5 banks belonging to book category 4 which entered into LQ45 Index namely Bank Mandiri, Bank Central Asia (BCA), Bank Rakyat Indonesia (BRI) and Bank Negara Indonesia BNI) while for Bank CIMB Niaga became the last bank entered into the new Book 4 category in the press release on April 25, 2017. The research that supports this research, among others, Research on the valuation of intrinsic value of shares has been done by some researchers, by Until now there are several methods that can be used in doing corporate valuation, some of them with Discounted Cash Flow method with several approaches such as Discounted Dividend Model (DDM) and Free Cash Flow to Equity (FCFE). The main reason why using the Discounted Dividend Model (DDM) approach is based on research conducted by [2], said that the valuation model closest to the actual value is using Discounted Dividend Model while using the method of Free Cash Flow to Equity (FCFE) because FCFE has a more accurate indicator to calculate the cash flow received by shareholders.

[3] the definition of FCFE represents the cash flows available to shareholders, after all, operating costs, interest, and principal payments have been paid. In addition, the selection of FCFE valuation model is because each company must have cash flow which is the result of the company's operational activities, be it negative or positive cash flow, thus reflecting the actual condition of the company. And also this is because most shareholders will never know whether the dividends they received reflect the 
Model (DDM), Free Cash Flow to Equity (FCFE) and Free Cash Flow to the Firm (FCFF).

of Honda in the country of India. The results of the study use FCFE, intrinsic value in the overvalued state. Then use relative valuation. The intrinsic value in the undervalued state.

[5], [6], [7], [8] proving that intrinsic shares in the market are overvalued and undervalued. The study gives results that the stock price in the market does not reflect its fair value (intrinsic). Followed by the research of [9] where the results show that the value of stocks calculated using DFCF results close to the market average value, meaning in accordance with its fundamental value.

Therefore, based on the above background explanation, it is necessary to do research with the title " Test of FCFE Model and dividend discount model (DDM) in Book 4 Banking Companies Listed in Indonesia Stock Exchange ".

Based on the background of the above research, the problem formulation in this research are:

1. What is the fair price of shares in a banking company, by 2017 using the Free Cash Flow to Equity method on the growth scenario in a pessimistic, moderate and optimistic condition.

2. What is the fair price of shares in a banking company, by 2017 using the Dividend Discount Model method.

\section{LITERATURE REVIEW}

[10] to assess a company can use 3 (three) methods, namely:

1. Discounted Cash Flow Valuation, the value of an asset represents the present value of the estimated cash flow to be generated in the future expected future cash flow from an asset discounted by using a certain discount rate.

2. Relative Valuation, a valuation model that assesses an asset by comparing similar assets using the same variable as cash flow, book value, sales and earnings and usually used for comparison is the price earnings ratio (PER) and the price-book value ratio (PBV).

3. Contingent Valuation, using option pricing models to assess an asset that has properties such as options.

\section{Discounted Cash Flow Valuation (DCF)}

This Discounted Cash Flow approach is the foundation of all company valuation calculations. This approach tries to estimate the intrinsic value of an asset based on its fundamentals. Discounted Cash Flow is used to assess the equity in the business, assess the company as a whole and to assess a small part of the company (Damodaran, 2002). The DCF approach is the most commonly used model because it forms the basis of other valuation models. This model states that the value of an asset represents the present value of the expected cash flow to be generated in the future at a certain discount rate.

DCF model itself has three kinds of valuation approach according to their needs, such as: Dividend Discounted

Free Cash Flow to Equity

a.Free Cash Flow Equity is the cash flow received by the shareholders after the company fulfills all its obligations. With the following formula:

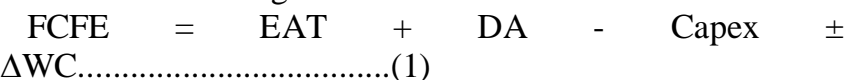

Weighted Average Cost of Capital (WACC) With the following formula:

WACC $=$ wdrd $(1-\mathrm{T})+$ wpsrps + wsrs

Terminal Value

$$
\mathrm{TV}=\frac{\text { FCFEn+1 }}{\text { WACC-gn }}
$$

Fair Value or Intrinsic Value per Stock is derived from dividing the Company's Equity with the Number of Shares circulated in the company by the following formula:

Fair Value $=\underline{\text { Value Equity }}$ shares outstanding

\section{Dividend Discounted Model}

DDM valuation method, assessing the intrinsic value of a company's shares based on the estimated revenue distributed to the Shareholders in the form of dividend and discounted its value to present value. DDM approach is an approach that in the analysis of the company is done by connecting between the expected cash flow dividend paid by the company for the shares owned. The following steps are used:

Dividend Growth Rate

$$
\mathrm{g}=\frac{D_{n}-D_{0}}{D_{0}}
$$

Where is:

$\mathrm{g}$ : Growth Rate
Dn : Current Dividend
D0 : Dividend of previous year
[11]

Dividend Estimation

Where is:

$$
D \mathrm{t}=D 0(1+g)
$$

Dt : Estimated Dividend

D0 : Dividend the previous year

g : Average Dividend Growth

[11]

Required Rate of Return

$$
\mathrm{k}={ }^{\frac{D}{P}}+\mathrm{g}
$$


The basis of this valuation is based on the assumptions and projections of the company's condition. This study is limited using historical data from 2012-2016 as the basis of projection. Then the projection is done to determine the future cash flow and calculated its present value. Valuation of shares using one of the two methods of valuation method that is by using Discounted Cash Flow with approach method of Free Cash Flow to Equity and Dividend Discount Model. In using the method required assumptions and projected determination of the condition of the company to obtain free cash flow in the future and then calculated the present value.

On the determination of assumptions and projections need to be adjusted to a certain scenario because the future is uncertain. There are several Scenarios that are determined and viewed based on Information on environmental data and facts. So on the basis of this study it uses three scenarios of Optimistic conditions (above industrial growth), moderate (most likely conditions), and pessimistic (below industrial growth).

Optimistic conditions are regarded as the highest growth conditions of the company and viewed from the difference between industry growth and corporate management targets. Moderate conditions are the most likely conditions that occur seen from the condition Fundamental company. While the pessimistic condition is the worst condition or condition under industrial growth. The final process of valuation is to obtain the value of equity or as the intrinsic value of the company which then will get intrinsic value for per shares in each scenario condition that exists.

\section{RESULTS AND DisCUSSION}

The purpose of this research is to find the fair value of companies in banking sub-sector by using DCF method with FCFE Approach and Discounted Dividend Model (DDM) with the result of calculation as the Table 1 below:

Table 1. Fair value of bbri, bbni,bmri,bbca using free cashflow to equity and dividend discounted model in 2017. valuation of intrinsic value is based on the assumptions and determination of the fundamental value projections of the firm.

\begin{tabular}{|c|c|c|c|c|c|}
\hline \multirow{4}{*}{ BBRI } & \multirow{3}{*}{ FCFE } & Optimistic & \multirow{3}{*}{11.675} & \multirow{3}{*}{$\begin{array}{l}8.767 \\
8.545 \\
8.066\end{array}$} & \multirow{3}{*}{$\begin{array}{l}\text { Overvalued } \\
\text { Overvalued } \\
\text { Overvalued }\end{array}$} \\
\hline & & Moderate & & & \\
\hline & & Pessimist & & & \\
\hline & DDM & Dividend & \multirow{6}{*}{5.525} & 14.128 & Undervalued \\
\hline \multirow{5}{*}{ BBNI } & & Optimistic & & 11.354 & Undervalued \\
\hline & FCFE & Moderate & & 10.338 & Undervalued \\
\hline & & Pessimist & & 8.466 & Undervalued \\
\hline & DDM & Dividend & & 6.497 & Undervalued \\
\hline & & Optimistic & & 16.998 & Undervalued \\
\hline \multirow{3}{*}{ BMRI } & FCFE & Moderate & \multirow{3}{*}{11.757} & 15.840 & Undervalued \\
\hline & & Pessimist & & 13.691 & Undervalued \\
\hline & DDM & Dividend & & 14.037 & Undervalued \\
\hline \multirow{4}{*}{ BBCA } & & Optimistic & \multirow{4}{*}{15.500} & 18.967 & Undervalued \\
\hline & FCFE & Moderate & & 17.499 & Undervalued \\
\hline & & Pessimist & & 14.683 & Undervalued \\
\hline & DDM & Dividend & & 16.678 & Undervalued \\
\hline
\end{tabular}

Source : Data processed Approach

\section{Stock Market Price}


Based on Table 1 above, it can be seen that the fair value of shares for BBRI, BBNI, BMRI and BBCA is calculated using two valuation methods, namely Free Cash Flow to Equity (FCFE) and Dividend Discounted Model (DDM), where the result has been compared with market share price date January 1, 2017 in order to assess the condition of shares in the market. The fair value of shares calculated using the FCFE method will result in a more precise target price. The resulting price target will be close to the stock price in the market in accordance with the fundamental aspects of the company. This is because the FCFE method has the advantage of projecting the company's performance to focus on revenue or revenues and operating activities with historical data and more detailed fundamental data. In addition, DCF method also has the advantage of providing the results of fair value in the form of price range in accordance with. optimistic scenario, moderate and pessimistic as alternative investment decision making. Investors can use the target price range as a benchmark or basis when the investor is in a seller's position (sell) or in a position as a buyer of shares (buy). Investors with stock sellers position can observe the highest price target position that is in the optimistic scenario, while the investor with the position as buyer of stock (buy) can observe the target position of the cheapest stock price that is in pessimistic scenario. Based on the supply and demand action between the buyer and the stock seller in the stock then the stock market price will be close to the price of the meeting or the price in a moderate scenario.

Furthermore, fair value calculated using Dividend Discounted Model (DDM) method, used in this study aims to validate the results of fair value estimation using the FCFE method. This means that when an investor plans to buy or sell shares in accordance with the target price range calculated using FCFE, investors can compare the target price using the valuation result using the Dividend Discounted Model (DDM) method.

Analyzing the stock price by using valuation method is appropriate because assessing stock is not based on personal assumption or majority who do excessive action when conducting stock transactions. However, from both methods analyzed, the condition of the stock price of the FCFE and DDM valuation results are shown to show the same result. The FCFE method produces an undervalued majority intrinsic value and only the BBRI stock price undergoes Overvalued using the FCFE method.

First for BBRI shares, it is known that BBRI share price on January 1, 2017 is $\mathrm{Rp} 11,675$ or in other words BBRI share price condition when compared with its fair price using FCFE on optimistic growth $(16,25 \%)$ is overvalued, at moderate growth $(15.25 \%)$ were in overvalued condition and in pessimistic growth (13.25\%) were in overvalued condition. Through FCFE method but with DDM method result obtained at Undervalued condition with fair value equal to Rp.14.128. So the market price should be close to or will not be far behind the price range in a moderate scenario, since a moderate scenario is the most likely scenario.

Second for BBNI stock, it is known that BBNI stock price on January 1, 2017 is Rp 5,525 meaning BBNI stock price condition when compared with its fair value using FCFE on optimistic growth $(21 \%)$ is Undervalued, on moderate growth $(18,41 \%)$ are in Undervalued condition, and in pessimistic growth $(13.25 \%)$ are in Undervalued condition. Through FCFE method, meaning BBNI stock has a price range of $11,354-6,497$, if BBNI stock price on January 1, 2017 compared with the fair price using Discounted Dividend Models then BBNI stock price is $\mathrm{Rp}$ 6,497 in undervalued condition. Thus, BBNI shares as a whole are in undervalued condition

Third for BMRI shares, it is known that BMRI share price on January 1, 2017 is Rp 11,757 meaning that the stock price of BMRI when compared with its fair value using DCF on optimistic growth $(19,78 \%)$ is undervalued, at moderate growth $(17,60 \%)$ are in undervalued and pessimistic growth (13.25\%) and the target price in moderate scenario for BMRI is Rp 15,840. But in this moderate scenario BMRI stock prices are in an undervalued state, meaning that the BMRI price> BMRI share price in the market indicating BMRI share price is in cheap category.

And Last BBCA shares, it is known that BBCA share price on January 1, 2017 is Rp 15,500 or in other words BBCA share price condition when compared with its fair price using FCFE on optimistic growth $(17,53 \%)$ is undervalued, at moderate growth ( $16.10 \%)$ are under the condition .

\section{CONCLUSIONS}

Findings from this research, some conclusions as follows: (1)The method of valuation of Free Cash Flow to Equity (FCFE) can be applied in calculating the fair price of shares, where 3 stocks based on FCFE model shows undervalued such as BBNI, BMRI and BBCA while for BBRI shows Overvalued from all approaches that exist optimistically, Moderate and pessimists. (2) The Dividend Discounted Model (DDM) valuation method can be applied in calculating the fair price of shares, in which the results show that all stock are undervalued such as BBRI, BBNI, BMRI and BBCA. 


\section{REFERENCES}

[1] Dermawan Sjahrial, Manajemen Keuangan, Jakarta: Mitra Wacana Media, p.13, 2009

[2] Wijaya, Chandra dan Nurdessy Nirmala. (2007). Perbandingan Model Valuasi Harga Saham Pengujuan Empiris Pada Saham Yang Terdaftar di BEJ Tahun 2004. Jurnal Tepak Manajerial Magister UNRI. vol 7 no 7 (http://isjd.pdii.lipi.go.id, diakses 16 Februari 2013

[3] Pinto, Jerald E. ,Elaine Henry, Thomas R. Robinson, John D. Stowe, \& Abby Cohen, Equity Asset Valuation. John Willey \& Sons, Inc, 2010

[4] Panda, Shradhanjali, Comparision of Fundamental Value and Market Value: A Case Study of Heromotoco. International Journal of Humanities and Social Science Invention. (ISSN 2319 - 7722), 2013

[5] Yulfita, Ulfa, Penilaian Harga Saham Sektor Manufaktur Yang Terdaftar Di Bursa Efek Indonesia (Periode 2009 2011). Jurnal Emba: Jurnal Riset Ekonomi, Manajemen, Bisnis Dan Akuntansi. (ISSN 2303-1174), 2013

[6] Muttaqim, Hakim, Analisis Valuasi Saham Pt. Adhi Karya (Persero) Tbk Dengan Metode Discounted Cash Flow (Dcf). Journal Of Economic Management \& Business. (ISSN: $1412-968 X), 2013$

[7] Khasanah, Nur dan Siti Aisjah. (2013). Penilaian Harga Saham dengan Dividend Discount Model dan Free Cash Flow to Equity Model (Studi pada Indeks Saham LQ45 di Bursa Efek Indonesia Periode 2007-2011). Jurnal Imiah Mahasiswa FEB Universitas Brawijaya. (Vol 1, No 2: Semester Genap 2012/2013)

[8] Pratama, Aditya Surya. 2010. Analisis Valuasi Harga Saham Pt Bank Negara Indonesia, Tbk Dengan Metode Free Cash Flow To Equity Dan Relative Valuation. Thesis FE UI.

[9] Ivanovski, Zoran,Zoran Narasanov, dan Nadica Ivanovska. (2015) . Accuracy Of Dividend Discount Model Valuation At Macedonian Stock- Exchange. Journal of International Scientific Publications. (ISSN 1314-7242, Volume 9, 2015)

[10] Damodaran, Aswath , Investment Valuation: Tools and Techniques for Determining the Value of Any Asset; John Wiley \& Sons, 2002

[11] Tandelilin, Eduardus. (2010). Portofolio dan Investasi Teori dan Aplikasi. Edisi pertama. Yogyakarta : Kanisiu 